\title{
Endocannabinoid modulation of dopamine neurotransmission
}

\author{
Dan Covey ${ }^{1}$, Yolanda Mateo², David Sulzer ${ }^{3,4,5,6}$, Joseph F. Cheer ${ }^{7,8,9}$, and David M. \\ Lovinger ${ }^{2, *}$ \\ ${ }^{1}$ Department of Anatomy and Neurobiology, University of Maryland School of Medicine, Baltimore, \\ MD, USA
}

${ }^{2}$ Section on Synaptic Pharmacology, Laboratory for Integrative Neuroscience, National Institute on Alcohol Abuse and Alcoholism, National Institutes of Health, Rockville, MD 20852, USA

${ }^{3}$ Department of Neurology, Columbia University, New York, NY 10032

${ }^{4}$ Department of Psychiatry, Columbia University, New York, NY 10032

${ }^{5}$ Department of Pharmacology, Columbia University, New York, NY 10032

${ }^{6}$ New York State Psychiatric Institute, New York, NY 10032

${ }^{7}$ Department of Psychiatry, University of Maryland School of Medicine, Baltimore, Maryland, USA

${ }^{8}$ Program in Neuroscience, University of Maryland School of Medicine, Baltimore, Maryland, USA

${ }^{9}$ Department of Anatomy and Neurobiology, University of Maryland School of Medicine, Baltimore, Maryland, USA

\section{Abstract}

Dopamine (DA) is a major catecholamine neurotransmitter in the mammalian brain that controls neural circuits involved in the cognitive, emotional, and motor aspects of goal-directed behavior. Accordingly, perturbations in DA neurotransmission play a central role in several neuropsychiatric disorders. Somewhat surprisingly given its prominent role in numerous behaviors, DA is released by a relatively small number of densely packed neurons originating in the midbrain. The dopaminergic midbrain innervates numerous brain regions where extracellular DA release and receptor binding promote short- and long-term changes in postsynaptic neuron function. Striatal forebrain nuclei receive the greatest proportion of DA projections and are a predominant hub at which DA influences behavior. A number of excitatory, inhibitory, and modulatory inputs orchestrate DA neurotransmission by controlling DA cell body firing patterns, terminal release, and effects on postsynaptic sites in the striatum. The endocannabinoid (eCB) system serves as an important filter of afferent input that acts locally at midbrain and terminal regions to shape how incoming information is conveyed onto DA neurons and to output targets. In this review, we aim to highlight existing knowledge regarding how eCB signaling controls DA neuron function through

"corresponding author: David M. Lovinger, National Institute on Alcohol Abuse and Alcoholism, National Institutes of Health, 5625 Fishers Lane, Room TS-13A: MSC 9411, Bethesda, MD 20892-9412, lovindav@ mail.nih.gov.

Publisher's Disclaimer: This is a PDF file of an unedited manuscript that has been accepted for publication. As a service to our customers we are providing this early version of the manuscript. The manuscript will undergo copyediting, typesetting, and review of the resulting proof before it is published in its final citable form. Please note that during the production process errors may be discovered which could affect the content, and all legal disclaimers that apply to the journal pertain. 
modifications in synaptic strength at midbrain and striatal sites, and to raise outstanding questions on this topic.

\section{Introduction}

The dopamine (DA) molecule is a major CNS neurotransmitter that has been the focus of extensive study due to its prominent involvement in core behavioral processes - including motor control, motivation, learning, and memory - and contribution to several neuropsychiatric disorders - including Parkinson's disease, schizophrenia, and drug addiction (Iversen et al., 2010). DA influences behavioral output by modulating basal ganglia circuit function. This occurs in large part through actions in the striatum, the primary input nucleus of the basal ganglia and predominant afferent target of midbrain DA cell bodies (Midbrain-forebrain DA circuits). Research into this mesostriatal DA circuit has revealed a crucial regulatory role for the endocannabinoid $(\mathrm{eCB})$ system, a vast signaling network that controls synaptic transmission throughout the brain and periphery (Brief primer to endocannabinoid signaling). Notably, many behaviors and disease states that have traditionally been conceptualized as 'DA-dependent' are now understood to arise from interactions between the eCB and DA systems, including motor control or motor disorders (Garcia et al., 2016) and reward seeking or addiction (Parsons and Hurd, 2015). Regulation of DA neurotransmission by eCBs arises through modulation of DA neuron effector sites in the striatum (Endocannabinoid control of striatal function), DA neuronal activity at midbrain cell bodies (Endocannabinoid control of DA neurons in midbrain), and DA release at axon terminal endings (Endocannabinoid control of terminal DA release). Recent work indicating additional mechanisms by which eCB signaling controls DA function (CB2 receptor regulation of DA function) suggests these two systems are even more unified than previously thought. While several questions remain regarding the precise location and mechanisms by which eCBs and DA neurons communicate, it is clear that an understanding of DA neurotransmission cannot be fully realized independently of its relationship with eCB signaling.

\section{Midbrain-forebrain DA circuits}

The defining feature of a dopaminergic neuron is an ability to synthesize DA and release it both locally and at distal axon terminals (Subramaniam and Roeper, 2017; Sulzer et al., 2017). DA is synthesized by tyrosine hydroxylase and aromatic L-amino acid decarboxylase in neuronal cytosol, and packaged into synaptic and dense core vesicles via the vesicular monoamine transporter (VMAT) (Anden, 1967; Carlsson et al., 1958; Scherman et al., 1988). Vesicular release occurs in a calcium-dependent manner from both somatodendritic and axonal compartments (Beart et al., 1979; Beckstead et al., 2004; Besson et al., 1969; Bustos and Roth, 1972). Dopaminergic cell bodies originate within discrete midbrain nuclei known as the retrorubral field (A8), substantia nigra pars compacta (SNc, A9), and ventral tegmental area (VTA, A10) (Hillarp et al., 1966). Dopaminergic neurons densely innervate the dorsal and ventral striatum (i.e., nucleus accumbens, NAc), and project more sparsely to certain cortical subregions including the hippocampus and prefrontal cortex, thus comprising the mesocorticolimbic DA system. DA affects target neurons via 5 subtypes of G protein- 
coupled receptors (GPCRs) that come in two general classes, those that predominantly couple to $\mathrm{Ga}_{\text {s/olf }}$ heterotrimeric $\mathrm{G}$ proteins (D1 and D5 receptors), and those that predominantly couple to $\mathrm{Ga}_{\mathrm{i} / \mathrm{o}} \mathrm{G}$ proteins (D2-D4 receptors) (Lachowicz and Sibley, 1997; Neve et al., 2004). Thus, DA is a 'pure' neuromodulator that exerts slow control over fast neurotransmission, in contrast to many other neurotransmitter systems that have both fastacting ionotropic and slower acting GPCR-mediated actions.

Receptor activation dissociates the $\mathrm{G}$ protein heterotrimeric complexes to liberate $\mathrm{Ga}$ and $\mathrm{G} \beta / \gamma$ subunits (Latek et al., 2012). $\mathrm{Ga}_{S}$ stimulates adenylyl cyclase (AC), which activates a variety of intracellular signaling systems that depolarize neurons, while $\mathrm{Ga}_{\mathrm{i} / \mathrm{o}}$ liberation inhibits AC and suppresses these systems. $G \beta / \gamma$ subunits also have signaling functions, including activation of phospholipase $\mathrm{C}$ (PLC) and modulation of certain ion channels that ultimately suppresses neuronal activity (Oldham and Hamm, 2006). This includes activation of G protein-coupled Inwardly-Rectifying Potassium (GIRK) channels and inhibition of voltage-gated calcium channels (VGCCs) (Betke et al., 2012). Once released, extracellular DA is subject to a number of regulatory mechanisms. The DA transporter (DAT) mediates fast DA re-uptake at cell bodies, dendrites, and axon terminals, and constitutes the main mechanism controlling DA concentrations at extrasynaptic sites, although the norepinephrine transporter also supports DA re-uptake in the prefrontal cortex (Carboni et al., 1990). DA degradation is primarily catalyzed by monoamine oxidase in striatum, and in some regions catechol-o-methyltransferase plays a dominant role.

DA neuron somata and dendrites are activated, inhibited, and modulated by several neurotransmitter systems arising from numerous brain regions, as recently reviewed (Sulzer et al., 2016; Paladini and Tepper, 2017). For the purposes of this review, we highlight here prominent inputs that control DA neurotransmission and explain in subsequent sections how these inputs are regulated by endocannabinoid $(\mathrm{eCB})$ signaling. In general., glutamatergic inputs excite midbrain neurons through activation of ionotropic, and to some extent metabotropic, glutamate receptors on somatodendritic regions (Morikawa et al., 2003). However, the M5 metabotropic glutamate receptor, the only one reported to be expressed by midbrain DA neurons, exerts complex effects on terminal DA release (see below).

GABAergic inputs generally inhibit DA function via $\mathrm{GABA}_{\mathrm{A}}$-type anion-fluxing ionotropic receptors and $\mathrm{GABA}_{\mathrm{B}}$-type Gi/o-coupled metabotropic receptors, although notable differences exist in the anatomical and functional characteristics of the GABA receptor subtypes (for review see Paladini and Tepper, 2017). Midbrain DA neurons also receive prominent neuromodulatory inputs, including particularly dense projections from serotonergic neurons in the dorsal raphe (Watabe-Uchida, 2012), although these projections also release glutamate onto DA neurons in the VTA (Qi et al., 2014). Finally, autoregulation can occur via DA release at somatodendritic compartments or terminals, which provides feedback inhibition through presynaptic DA D2 receptor (D2-R) binding (Beart and McDonald, 1982; Beckstead et al., 2004; Ford et al., 2009).

DA neurotransmission is also modulated at release sites in the striatum by several afferent inputs (Cachope and Cheer, 2014), including cholinergic and glutamatergic sources, which can control terminal DA release independently of DA cell body input (Figure 1). Acetylcholine (ACh) released from striatal cholinergic interneurons (CINs; Fig 1B) binds 
ionotropic nicotinic $\mathrm{ACh}(\mathrm{nACh})$ receptors on DA terminals, which increases intracellular calcium flux (Zhou et al. 2001; Exley and Cragg, 2008) and elicits DA release in the NAc and dorsal striatum (Cachope et al., 2012; Threlfell et al., 2012). The nACh-R subtypes involved in this release are of the a $4 / 6 \beta 2$ variety with a 4 perhaps predominating in dorsal striatum and a6 in NAc (Rapier et al., 1990; Zhou et al., 2001; Exley and Cragg, 2008; Cachope et al., 2012; Threlfell et al., 2012). CINs also target muscarinic ACh (mACh) GPCRs, which are of the $\mathrm{G}_{\mathrm{q} / 11^{-}}$-coupled M5 subtype on DA terminals. Activation of M5 mACh-Rs in dorsal striatal (Foster et al., 2014) or NAc (Shin et al., 2015) brain slices inhibits DA released by electrical stimulation (Foster et al., 2014). In contrast, a non-specific $\mathrm{mACh}-\mathrm{R}$ agonist, oxotremorine $\mathrm{M}$, potentiates DA release in response to selective optogenetic stimulation of DA neuron axon projections, achieved through virally-mediated expression of channelrodopsin-2 in the VTA. This selective potentiation of DA release requires M5 mACh-R expression on DA neurons (Shin et al., 2015). By non-specifically depolarizing the terminal field, electrical stimulation likely reveals a polysynaptic route by which M5 mACh-Rs inhibit DA release, while optogenetic measures presumably reflect a direct action of M5 mACh-Rs on DA neuron terminals. ACh release onto presynaptic $\mathrm{G}_{\mathrm{i} / \mathrm{o}^{-}}$ coupled M2/M4 mACh autoreceptors provides another source of regulation through feedback inhibition of CIN output (Shin et al., 2015; Threlfell et al., 2010). Finally, CINs can modulate DA terminals by regulating striatal glutamate release that arises from 'noncanonical' glutamatergic neurons. For example, M5 mACh-Rs potentiate glutamate released from VGluT 2 $_{2}$-expressing DA terminals (Shin et al., 2015), and striatal CINs, which express VGluT $_{3}$, also release glutamate in the striatum (Higley et al., 2011; Nelson et al., 2014). Similar to ACh, glutamate shapes striatal DA release through direct and indirect actions involving ionotropic and metabotropic receptors (Fig 1C). Somewhat surprisingly, local application of ionotropic glutamate receptor agonists (kainate, AMPA, and NMDA) inhibit DA release (Wu et al., 2000; Kulagina et al., 2001; Ashalumov et al., 2003), while AMPA receptor antagonists increase DA released in striatal slices, specifically following pulse train stimulation (Avshalumov et al., 2003, 2008). This inhibitory effect on DA release likely arises via an indirect mechanism because ionotropic glutamate receptors are not thought to reside on DA terminals (Chen et al., 1998). However, metabotropic M1 glutamate receptors (mGlu-R1s) are expressed by DA terminals (Paguet and Smith, 2003) and their activation following electrical stimulation of corticostriatal afferents also inhibits DA release in striatal brain slices (Zhang and Sulzer, 2003). Alternatively, glutamatergic signaling can elicit DA release at striatal terminals via ionotropic glutamate receptors on striatal CINs, which supports feed-forward activation of DA release via terminal nACh-Rs (Kosillo et al., 2016). Clearly, future work is necessary for identifying the location and mechanism by which cholinergic and glutamatergic inputs control terminal DA release. Recent work indicates an important role for eCBs in regulating this circuit, as discussed below (Endocannabinoid control of terminal DA terminal).

\section{Brief primer to endocannabinoid signaling}

The eCBs are signaling fatty acids derived from arachidonic acid-containing phospholipids (Kano et al., 2009; Katona and Freund, 2012; Castillo et al., 2012). Primary eCBs in the CNS are arachidonoyl ethanolamide (AEA, also known as anandamide) and 2-arachidonoyl 
glycerol (2-AG). Both molecules produce juxtacrine and paracrine actions through activation of $\mathrm{G}_{\mathrm{i} / \mathrm{o}}$-type GPCRs known as cannabinoid receptors. The predominant cannabinoid receptors, deemed CB1 and CB2, are ubiquitously expressed throughout the body. The CB1 receptor is especially enriched in the nervous system and is primarily localized to axon terminal endings (Herkenham et al., 1990, Katona et al., 1999; Nyiri et al., 2005; Tsou et al., 1998), while the CB2 receptor is expressed at much higher levels in the periphery and resides at pre- and post-synaptic sites. However, recent work demonstrates that functional CB2 receptors are also expressed in the brain (see below). Both receptors are primary targets of $\Delta^{9}$-tetrahydrocannabinol $\left(\Delta^{9}\right.$-THC), the major psychoactive ingredient in Cannabis sativa. In general., cannabinoid receptor activation decreases neurotransmitter release via inhibition of VGCCs (Betke et al., 2012; Caulfield and Brown, 1992; Graham et al., 1974; Ishac et al., 1996; Kushmerick et al., 2004; Mackie and Hille, 1992; Shen et al., 1996), inhibition of AC, and activation of GIRK channels.

CB1 receptor signaling in the brain typically arises 'on-demand', in that it is dependent on de novo synthesis and retrograde release of eCBs from postsynaptic sites onto CB1expressing terminals (Fig 1D; Castillo et al., 2012; Ohno-Shosaku et al., 2014). 2-AG is the primary eCB involved in this retrograde inhibition of synaptic activity in the brain (Kreitzer and Regehr, 2001; Ohno-Shosaku et al. 2001; Wilson and Nicoll, 2001). Mobilization of 2AG requires the biosynthetic enzyme, sn-1-diacylglycerol lipase-alpha (DGLa), which is densely expressed in the plasma membrane at dendritic spines postsynaptic to CB1 receptorexpressing terminals. Membrane depolarization, activation of metabotropic receptors that

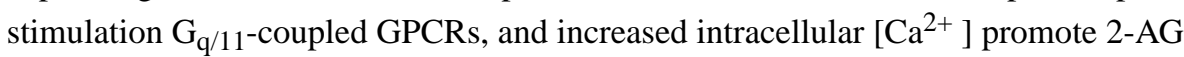
production by activating a cascade of intracellular events involving phospholipase-C- $\beta$ (PLC- $\beta$ )-dependent production of 1,2-diacylglycerol, which is hydrolyzed by DGLa to form 2-AG (Hashimotodani et al., 2005; Maejima et al., 2001; Tanimura et al., 2010; Varma et al., 2001). The canonical mode of eCB signaling has been best characterized in brain regions where the requisite molecular machinery is densely expressed, including the hippocampus, cerebellum, cortex, and striatum, where binding of postsynaptically-synthesized 2-AG to presynaptic CB1 receptors promotes short-term and long-term depression (STD/LTD) of neurotransmitter release. STD is defined as persisting only while the eCB is active at CB1 receptors (Heinbockel et al., 2005) and occurs following brief ( $\leq 0 \mathrm{~s}$ ) depolarization of postsynaptic neurons. This form of plasticity occurs at glutamatergic (excitatory) and GABAergic (inhibitory) synapses where it is termed depolarization-induced suppression of excitation (DSE) or inhibition (DSI), respectively. Activation of $\mathrm{G}_{\mathrm{g} / 11^{-} \text {-coupled receptors can }}$ also trigger eCB synthesis (Hashimotodani et al., 2007) and eCB-STD through intracellular signaling cascades that activate PLC- $\beta$ (Castillo et al., 2012). This receptor-mediated inhibition can occur independently of DSE/I or can potentiate DSE/I if GPCR activation coincides with postsynaptic depolarization.

Similar mechanisms drive eCB-mediated long-term depression (eCB-LTD), which persists for at least 1 hour after cessation of the induction protocol, well after CB1 receptor binding has ceased (Yin et al., 2006). Induction of eCB-LTD requires strong and persistent synaptic activity that coincides with the requisite intracellular molecular signals in presynaptic terminals. Similar to DSI/DSE, eCB-LTD is observed at both GABAergic and glutamatergic synapses throughout the brain, is initiated by retrograde release of postsynaptically- 
synthesized eCBs, and requires presynaptic $\mathrm{CB} 1$ receptor activation. However, $\mathrm{CB} 1$ antagonists only disrupt eCB-LTD when present during, or just after, induction, but not once synaptic depression is established. Thus, CB1 receptor binding sets into motion a series of molecular events that acquire independence from CB1 receptor activity. In addition to CB1 receptor signaling, eCB-LTD also requires increased intracellular calcium at the presynaptic terminal - typically elicited by repetitive depolarization (Heifets et al., 2008; Mato et al., 2008) - and inhibition of AC by CB1-linked $\mathrm{Ga}_{\mathrm{i} / \mathrm{o}}$ signaling, leading to inhibition of protein kinase A and decreased phosphorylation of substrates such as the vesicle-associated Rim1 proteins (Chevaleyre et al., 2007; Mato et al., 2008). Increased protein translation at the presynaptic terminal is also necessary for eCB-LTD expression (Yin et al., 2006, Younts et al., 2016). The net result of these processes is a long-lasting decrease in the probability of presynaptic vesicle fusion and neurotransmitter release at most synapses (but see Carey et al., 2011). The necessary infrastructure for eCB-mediated plasticity is present at both DA cell body and terminal regions, allowing fine-tuned regulation of DA neuronal activity and its influence on target neurons.

\section{Endocannabinoid control of striatal function}

In the striatum, CB1 receptors are expressed at presynaptic terminals of GABAergic interneurons, glutamatergic projection neurons, and local collaterals from GABAergic medium spiny neurons (MSNs) (LaFourcade et al., 2007; Fitzgerald et al., 2012). CB1 receptor expression levels are highest in the dorsolateral striatum and decrease along a ventromedial gradient (Martin et al., 2008). DGLa is expressed in the plasma membrane of MSN dendritic spines (Uchigashima et al., 2007) and is required for 2-AG-mediated retrograde suppression of synaptic transmission in the striatum (Tanimura et al., 2010). CB1 receptors on glutamatergic terminals arising from the prefrontal cortex are particularly important for LTD of corticostriatal and coritcoaccumbens synapses, a form of activitydependent plasticity that is important for action initiation, motor learning, and habit formation (Jin and Costa, 2015; Hilario et al., 2008). The most common LTD protocol is high-frequency-evoked LTD (HFS: $100 \mathrm{~Hz}$ ) and this engages the convergent activity of DA D2-Rs-nd mGlu-R1s (mGlu-R1: encompassing mGlu-R1 and mGlu-R5 subtypes) on MSNs (Yin and Lovinger, 2006; Wang et al., 2012; Plotkin et al., 2013). In contrast, LTD evoked by low-frequency stimulation - closer to normal cortical firing frequencies (LFS: $10 \mathrm{~Hz}$ ) requires postsynaptic DA receptor activation (D1 or D2 type), but not mGlu-R1 activation, and occurs in the absence of MSN depolarization (Ronesi and Lovinger, 2005). Both HFS and LFS LTD protocols require eCB release from MSNs and CB1 receptor binding at presynaptic corticostriatal terminals (Gerdeman and Lovinger, 2001; Tanimura et al., 2010).

An alternate means to measure corticostriatal plasticity uses a label for recycling synaptic vesicles, the endocytic probe FM1-43, and enables measurement of activity at individual presynaptic sites (Wong et al., 2011). In these studies, DA inhibits the fusion of synaptic vesicles at corticostriatal synapses in a D2-R dependent manner, a phenomenon labeled 'chronic presynaptic depression' (CPD), a form of plasticity that may last for the life of the animal (Bamford et al., 2008; Storey et al., 2016). This optical approach resolves that DAdependent inhibition is spared at the most active synapses, providing a 'high-pass filter' of corticostriatal input (Bamford et al., 2004; Bamford et al., 2008). D2-R-dependent CPD and 
filtering of corticostriatal excitation is, like LTD, dependent on presynaptic CB1-R activation (Wang et al., 2012; Wong et al., 2015). Indeed, while inhibiting CB-Rs does not directly disrupt corticostriatal activity, it occludes D2-R-dependent CPD. In unilaterally DA depleted mice that show 'supersensitive' D2-Rs, CB1 receptor inhibition additionally suppresses the most active terminals. The role for CB1-Rs in presynaptic inhibition is downstream from activation of mGlu-R5 and D2-R, as CB1-R antagonists block D2-R effects and CB1-R agonists inhibit this activity without D2-R activation (Wong et al., 2015).

LTD and CPD may represent aspects of a common form of retrograde eCB-dependent inhibition of synaptic transmission. However, the precise mechanisms responsible for eCB effects may vary: HFS-LTD requires depolarization of MSNs by ionotropic glutamate receptors to open L-type calcium channels (Adermark et al., 2009; Plotkin et al., 2013) while LFS LTD requires eCB transmission but not postsynaptic depolarization, NMDA, AMPA, or mGlu-R1 activation (Ronesi and Lovinger, 2005). Alternatively, LFS-CPD requires D2-R, mGlu-R5, and CB1 receptor (Wong et al., 2015). As mGlu-R5 and D2-R are located extrasynaptically, and as high corticostriatal activity can lead to glutamate spillover that activates extrasynaptic metabotropic glutamate receptors (Zhang and Sulzer, 2003), it may be that when glutamate and DA both engage in extrasynaptic neurotransmission, the resulting release of eCBs allows transmission from the most active corticostriatal terminals and inhibits the less active synapses. This requirement for combinatorial synaptic activity could serve as a coincidence detector that supports sensorimotor learning mechanisms, as synaptic selection would only occur during convergent extrasynaptic transmission of DA activated by environmental stimuli and extrasynaptic activation of mGlu-R5 during physiologically relevant levels of cortical activity. The means by which active terminals evade inhibition remains unknown, but a possibility is that high calcium or cAMP levels may override eCB signaling.

\section{Endocannabinoid control of midbrain DA neurons}

Dopaminergic cell bodies projecting to striatal regions arise in the VTA and SNc complex, of which they comprise $\sim 50-90 \%$ of the neurons depending on the subregion (Ungless and Grace, 2012; Margolis et al., 2006). Activity patterns of the dopaminergic midbrain consist of slow (2-4 Hz), asynchronous tonic firing patterns that briefly shift to phasic $(15-30 \mathrm{~Hz})$ bursts, although anatomical heterogeneity in neuronal activity is pronounced (Lammel et al., 2014). Terminal DA release is highly sensitive to cell body firing frequency, and bursting patterns can elicit transient ( 1-2 s), high concentration release events in terminal regions, particularly the NAc (Zhang et al., 2009). This phasic DA activity is important for ascribing value to environmental events and motivating action. For example, phasic firing and release in the NAc is elicited by reward receipt, but inhibited by aversive stimuli (Roitman et al., 2008; Ungless et al., 2004; but see Bromberg-Martin, 2010). Moreover, cues predicting rewarding or aversive events increase phasic signaling coincident with action initiation (Oleson et al., 2012; Syed et al., 2016). These stereotyped activity patterns are driven by excitatory and inhibitory inputs arising from numerous afferent structures and interneurons that are filtered by local eCB signaling at midbrain DA neurons. 
While DA neurons do not express CB1 receptors (Julian et al., 2003), CB1 receptors tightly regulate DA neuronal activity. CB1 agonists (including $\Delta^{9}$-THC) increase DA cell firing in the SNc and VTA (French et al., 1997; Cheer et al., 2003), and DA release in the NAc (Cheer et al., 2004; Tanda et al., 1997) in vivo. Additionally, local application of CB1 agonists in brain slice preparations increases singe-spike firing and bursting rates of DA neurons (Cheer et al., 2000), indicating that CB1 receptors control DA activity through modulation of local circuitry in the midbrain. CB1 receptors are expressed at presynaptic inputs to DA neurons (Matyas et al., 2008; Fitzgerald et al., 2012) and facilitate or suppress DAergic neuron activity depending on their presynaptic locus. By decreasing the probability of neurotransmitter release, $\mathrm{CB} 1$ receptors on GABAergic terminals can facilitate DAergic activity through suppression of inhibitory input onto $\mathrm{GABA}_{\mathrm{A}}$ or $\mathrm{GABA}_{\mathrm{B}}$ receptors on DA neurons (Szabo et al., 2002; Riegel and Lupica, 2004; Melis et al., 2013; Wang et al., 2015). Alternatively, CB1 receptors at glutamatergic synapses suppress excitatory drive onto AMPA or NMDA receptors on DA neurons (Melis et al., 2004a,b;Riegel and Lupica, 2004; Melis et al., 2006). The mechanism of this presynaptic inhibition is similar in DA neurons of the SNc and VTA, although the affected inputs are likely distinct (Watabe-Uchida et al., 2012).

Endogenous modulation of DA neurons via $\mathrm{CB} 1$ receptor signaling is largely accomplished by the eCB 2-AG (Figure 2). As is the case for striatal MSNs, DGLa is expressed on the plasma membrane of DA neurons at postsynaptic sites opposing CB1 receptor-expressing terminals (Matyas et al., 2008), providing the requisite infrastructure for retrograde $\mathrm{eCB}$ transmission. Stimuli that increase DA neuronal firing and bursting activity support 2-AG mobilization and transient inhibition of afferent input via DSI and DSE (Riegel and Lupica, 2004; Wang et al., 2015), allowing DA neurons to regulate incoming signals and orchestrate ongoing activity patterns. Retrograde inhibition of synaptic input to midbrain DA neurons is also triggered by eCB release following activation of a number of $\mathrm{G}_{\mathrm{q} / 11}$ PCRs that target intracellular PLC- $\beta$, including mGlu-R5 glutamate receptors (Pan et al., 2008), a 1 noradrenergic receptors (Wang et al., 2015), OX1 orexin receptors (Tung et al., 2016), and NT1 neurotensin receptors (Kortleven et al., 2012). Similar to the striatum, receptormediated eCB release can occur independently of elevated $\left[\mathrm{Ca}^{2+}\right]$ or simultaneously to synergistically potentiate $2-\mathrm{AG}$ production. Synergistic activity is important for promoting the induction, but not expression (but see Kortleven et al., 2012), of LTD at inhibitory (i.e., ILTD) and excitatory synapses (Pan et al., 2008; Zhong et al., 2015; Kortleven et al., 2012; Labouèbe et al., 2013). Co-activation of CB1 receptors and DA D2-Rs at presynaptic terminals also supports I-LTD induction through synergistic inhibition of intracellular cAMP/PKA signaling and decreased neurotransmitter release (Pan et al., 2008).

Modification of presynaptic input via activity-dependent 2-AG mobilization controls dopaminergic processing of reward. Midbrain DA neurons receive extensive GABAergic input from numerous brain regions that provides tonic inhibition of spontaneous activity (Paladini and Tepper, 2017). Removing this inhibitory constraint using $\mathrm{GABA}_{\mathrm{A}}$ or $\mathrm{GABA}_{\mathrm{B}}$ antagonists increases tonic firing and bursting rates of DA neurons (Lobb et al., 2010). Moreover, optogenetic experiments demonstrate that selectively inhibiting GABAergic input to VTA DA neurons evokes phasic DA release in the NAc (Nieh et al., 2016) and rewardseeking (Stamatakis et al., 2013; Nieh et al., 2016), suggesting that eCB-mediated depression of GABAergic input can drive appetitive behavior. As mentioned above, 
retrograde 2-AG release onto $\mathrm{CB} 1$ receptors inhibits GABA release onto DA neurons (Riegel and Lupica, 2004; Lupica and Riegel, 2005) and, CB1 agonists and 2-AG degradation inhibitors (aimed at increasing tissue concentration) facilitate DA neuronal encoding of reward or reward-paired cues (Oleson et al., 2012b) and positive reinforcement maintained by intra-cranial self-stimulation (ICSS) of the VTA (Oleson et al., 2012b; but see Wiebelhaus et al., 2015). Notably, CB1 antagonists or 2-AG synthesis inhibitors do not typically disrupt DA cell firing (Cheer et al., 2000) or DA release in the NAc (Cheer et al., 2007; Covey et al., 2016; Wang et al., 2015) per se, but rather suppress increases evoked by pharmacological or behavioral manipulations. Thus, 2-AG exerts little tonic control of DA function, but is recruited 'on-demand' during periods of heightened activity. Accordingly, stimuli that enhance DA cell firing (e.g., rewards and associated cues) can promote 2-AG mobilization and initiate a positive feedback loop that facilitates subsequent DA function and appetitive behavior. Alternatively, eCB-mediated suppression of glutamatergic input to DA neurons can decrease reward processing. For example, elevated insulin signaling within the VTA elicits eCB-mediated LTD of DA neurons by suppressing glutamatergic input, and this decreased excitatory drive is associated with reduced food reward (Labouèbe et al., 2013). Whether eCB-dependent inhibition of glutamate input also elicits transient decreases in DA function evoked by aversive stimuli is yet to be determined.

Mounting evidence also identifies VTA eCB signaling as an important conduit by which addictive drugs access brain reward circuits (Lupica and Riegel, 2005; Parsons and Hurd, 2016). Drug reinforcement critically depends on drug-evoked elevations in brain DA levels, particularly in the NAc (Di Chiara and Imperato, 1988), which is thought to 'hijack' normal reward learning mechanisms (Hyman et al., 2006). Temporally-resolved measures of NAc DA dynamics using fast-scan cyclic voltammetry also demonstrate that - despite marked differences in cellular targets and pharmacological actions across drug classes - CB1 antagonists inhibit the ability of cannabinoids, nicotine, ethanol, cocaine, and amphetamine to elicit high concentration, phasic DA release events in awake animals (Cheer et al., 2007; Wang et al., 2014; Covey et al., 2016). This may explain the ability of CB1 antagonists to dramatically suppress drug reinforcement (Lupica and Riegel, 2005; Lazary et al., 2011). Given the on-demand nature of eCB signaling and low eCB tone in the VTA, CB1 receptors likely control drug-evoked DA signaling by responding to enhanced 2-AG levels. Indeed, recent work demonstrates that cocaine (Wang et al., 2015; Tung et al., 2016) and nicotine (Buczynski et al., 2016) trigger 2-AG synthesis in the VTA, which suppresses GABAergic input to disinhibit DA neurons.

Drug-induced activation of 2-AG-CB1 receptor signaling and inhibition of GABAergic transmission to VTA DA neurons is also critical to drug reward/reinforcement. An important role for eCBs in cocaine reward is indicated by work showing that intra-VTA infusions of a CB1 antagonist blocks acquisition of cocaine conditioned place preference, and I-LTD subsequently measured ex vivo (Pan et al., 2008). Stress-induced reinstatement of an extinguished cocaine conditioned place-preference is also controlled by 2-AG-CB1 receptor signaling (Tung et al., 2016). This process is dependent on OX1 orexin receptor activation on VTA DA neurons, which elicits receptor-mediated 2-AG mobilization onto GABAergic inputs and disinhibits DA neuronal firing. Similar mechanisms may underlie the ability of CB1 antagonists to suppress stress-induced reinstatement of drug seeking, which has been 
demonstrated for several drug classes (Fattore et al., 2007; Parsons and Hurd, 2016).

Additionally, microdialysis measures in the VTA show that nicotine-evoked increases in extracellular 2-AG levels coincide with decreases in GABA levels (Buczynski et al., 2016).

This effect is potentiated by chronic nicotine exposure (Buczynski et al., 2016), as would be expected following eCB-mediated I-LTD, and suppressed by disrupting 2-AG synthesis in the VTA. Local DGLa inhibition also decreases nicotine self-administration, indicating that 2-AG production and suppression of inhibitory drive to the VTA serves a critical role in nicotine reinforcement. Such drug-induced decreases in inhibitory transmission may have the additional effect of facilitating LTP of excitatory glutamatergic synapses at VTA DA neurons (Liu et al., 2005), a well-characterized form of plasticity thought to critically support drug reinforcement (Luscher, 2013).

\section{Endocannabinoid control of terminal DA release}

In addition to the prominent actions at midbrain DA neurons, eCB signaling also controls DA release via local modulation of afferent terminal input onto DA axon terminals (Fig 1D). In accordance with the absence of CB1 receptors on DA neurons (Julian et al., 2003; Fitzgerald et al., 2012), in vitro voltammetry experiments in striatal brain slices demonstrate that CB1 receptors do not influence DA release in dorsal striatum evoked by single electrical pulse stimulation (Sidló et al., 2008; Szabo et al., 1999). However, a CB1 agonist inhibits DA released by stimulus trains (Sidló et al., 2008). This involves polysynaptic and indirect effects, including generation of $\mathrm{H} 2 \mathrm{O} 2$ by striatal MSNs, and activation $\mathrm{K}_{\mathrm{ATP}}$ channels in DA terminals. The stimulus-dependence of this effect is likely due to low eCB tone in the brain slice preparation that is increased by sustained depolarization. However, the precise location and mechanisms mediating eCB regulation of terminal DA release remain unclear.

As mentioned above, striatal MSNs possess the requisite molecular machinery for 'ondemand' production of eCBs, and $\mathrm{CB} 1$ receptors are located at presynaptic sites surrounding DA terminals (Uchigashima, 2007). Thus, eCB signaling can modify terminal DA function at several loci. Identifying the specific loci, however, has proven difficult. One potential source of eCB modulation are CINs, which profoundly influence DA terminals and, as stated above, have recently been shown to regulate DA release independently of cell body activation (Cachope et al., 2012; Threlfell et al., 2012; Zhou et al., 2001). Striatal CINs can also modulate local eCB signaling by facilitating depolarization-induced eCB release from striatal MSNs (Narushima et al., 2007). However, CB1 receptors are not found in striatal CINs (Hohmann and Herkenham, 2000; Uchigashima et al., 2007). Alternatively, CB1 receptors on glutamatergic afferents could directly modulate DA release at terminals in the striatum, but glutamate receptor control of terminal DA release remains poorly understood. For example, while striatal DA transmission is regulated by cortical input (Krebs et al., 1991; Zhang and Sulzer, 2003), the mechanism through which ionotropic glutamate receptors contribute is unclear because these receptors are not thought to be expressed on DA axons (Chen et al., 1998).

An important outstanding question is how DA release at axon terminals integrates eCB actions at cell body and terminal regions. Because eCBs are released "on-demand", the neuronal signals driving eCB release at cell body versus terminal regions are likely unique

Neuropharmacology. Author manuscript; available in PMC 2018 September 15. 
under certain conditions, allowing separable regulation at distinct neuronal loci.

Alternatively, actions at both sites may occur simultaneously. For example, systemically administered agonists may enhance DA neuron firing rates through disinhibition, but reduce the probability of DA release at terminal endings. In this situation, one might expect a decrease in DA-dependent behaviors (e.g. locomotor stimulation, intracranial selfstimulation) due to decreased DA output in forebrain target zones combined with enhanced DA release at somatodendritic sites and D2 autoreceptor-mediated inhibition of neuronal firing. Conversely, if eCB signaling at terminal regions is able to somehow facilitate DA release, a synergistic effect could arise. The net effect of CB1 actions at both sites will also depend on the baseline level of activity, such that enhancing DA neuronal firing may have a larger effect when baseline frequency is low compared to when neurons are bursting at nearmaximal frequencies. At the terminal zone, the impact of CB1 activation will depend on the extent of cortical input since $\mathrm{CB} 1$ receptors are confined to cortical terminal endings.

Accordingly, if DA release is driven primarily by midbrain or thalamic activation, then local eCB signaling will have little effect.

\section{CB2 receptor regulation of DA function}

Although 2-AG binds with equal affinity at the $\mathrm{CB} 1$ and $\mathrm{CB} 2$ receptors (Atwood and Mackie, 2010; Lu and Mackie, 2016), studies on eCB regulation of DA function have preferentially focused on the $\mathrm{CB} 1$ receptor. This is because $\mathrm{CB} 2$ receptors have historically been thought to reside primarily in the periphery, with high expression levels in the spleen and immune cells (Munro et al., 1993). However, recent evidence identifies CB2 receptor expression in several brain areas including the midbrain and striatum, and suggests an important role in modulating DA function. As mentioned above, CB2 receptors, similar to $\mathrm{CB} 1$ receptors, are $\mathrm{G}_{\mathrm{i} / \mathrm{o}}$-coupled and inhibit neuronal activity. In contrast to $\mathrm{CB} 1$ receptors, CB2 receptors are expressed by DA neurons (Zhang et al., 2015) and CB2 agonists inhibit DA neuronal firing and terminal release (Zhang et al., 2014; Zhang et al., 2016). CB2 receptor activation has also been recently shown to suppress drug reward (Xi et al., 2011). Moreover, a recent paper from Foster et al. (2016) indicates that CB2 receptor-dependent inhibition of striatal DA release is driven by ACh. The CB2-dependent inhibition of DA release was found to depend on M4 receptor activation on striatal D1-expressing MSNs and subsequent 2-AG mobilization onto CB2 receptors, presumably located on DA terminals. In general., the extent to which these CB2-mediated effects can be generalized to other neural circuits and behaviors is not yet clear because species differences in CB2 receptor structure and expression may underlie differential effects of CB2 manipulations in mice and rats (Liu et al., 2009; Zhang et al., 2015). Additionally, while exogenous activation of midbrain CB2 receptors influences DA neuronal activity and behavior, the endogenous factors and circumstances driving $\mathrm{CB} 2$ receptor signaling are not established.

\section{Summary and Conclusions}

Work presented herein highlights the important functional relationship between $\mathrm{DA}$ and $\mathrm{eCB}$ signaling in the regulation of brain function and behavior. Interactions between these two systems are prominent at each node of the mesostriatal DA circuit and critical to short- and long-lasting changes in DA neurotransmission. Practically, this work implicates eCB-based 
therapies as valuable treatments for disorders associated with aberrant DA function. Such an endeavor will require a better understanding of how eCBs and eCB manipulations influence behavior, especially over long-term treatment protocols. Theoretically, investigations into eCB control of DA neurotransmission have revealed important mechanisms by which neural circuits communicate through bidirectional synaptic signaling. A paucity of information remains, however, regarding the specific locale and conditions that drive $\mathrm{eCB}$ regulation of DA function. Because eCB signaling occurs at synapses possessing the requisite infrastructure (i.e., synthetic machinery and receptor expression), it is important that future work provides detailed anatomical and functional mapping of the afferent inputs that are subject to eCB modulation.

\section{Acknowledgments}

This work was supported by the following funding sources: NIDA F32DA041827 to DC, NIDA DA07418, NINDS MH108186, Parkinson's and JPB Foundations to DS, NIDA DA022340 DA042595 to JFC, and the NIAAA Division of Intramural Clinical and Biological Research, project number Z1A AA000416 involving YM and DML.

\section{References}

Adermark L, Talani G, Lovinger DM. Endocannabinoid-dependent plasticity at GABAergic and glutamatergic synapses in the striatum is regulated by synaptic activity. Eur J Neurosci. 2009; 29:32-41. [PubMed: 19120438]

Andén NE. Effects of reserpine and a tyrosine hydroxylase inhibitor on the monoamine levels in different regions of the rat central nervous system. Eur J Pharmacol. 1967; 1:1-5. [PubMed: 6058896]

Atwood BK, Mackie K. CB2: a cannabinoid receptor with an identity crisis. Br J Pharmacol. 2010; 160:467-479. [PubMed: 20590558]

Avshalumov MV, Patel JC, Rice ME. AMPA receptor-dependent $\mathrm{H} 2 \mathrm{O} 2$ generation in striatal medium spiny neurons but not dopamine axons: one source of a retrograde signal that can inhibit dopamine release. J Neurophysiol. 2008; 100:1590-1601. [PubMed: 18632893]

Avshalumov MV, Rice ME. Activation of ATP-sensitive K+ (K(ATP)) channels by $\mathrm{H} 2 \mathrm{O} 2$ underlies glutamate-dependent inhibition of striatal dopamine release. Proc Natl Acad Sci U S A. 2003; 100:11729-11734. [PubMed: 13679582]

Bamford NS, Zhang H, Joyce JA, Scarlis CA, Hanan W, Wu NP, Andre VM, Cohen R, Cepeda C, Levine MS, Harleton E, Sulzer D. Repeated exposure to methamphetamine causes long-lasting presynaptic corticostriatal depression that is renormalized with drug readministration. Neuron. 2008; 58:89-103. [PubMed: 18400166]

Bamford NS, Zhang H, Schmitz Y, Wu NP, Cepeda C, Levine MS, Schmauss C, Zakharenko SS, Zablow L, Sulzer D. Heterosynaptic dopamine neurotransmission selects sets of corticostriatal terminals. Neuron. 2004; 42:653-663. [PubMed: 15157425]

Beart PM, McDonald D. 5-Hydroxytryptamine and 5-hydroxytryptaminergic-dopaminergic interactions in the ventral tegmental area of rat brain. J Pharm Pharmacol. 1982; 34:591-593. [PubMed: 6127387]

Beart PM, McDonald D, Gundlach AL. Mesolimbic dopaminergic neurones and somatodendritic mechanisms. Neurosci Lett. 1979; 15:165-170. [PubMed: 43496]

Beckstead MJ, Grandy DK, Wickman K, Williams JT. Vesicular dopamine release elicits an inhibitory postsynaptic current in midbrain dopamine neurons. Neuron. 2004; 42:939-946. [PubMed: 15207238]

Bendor J, Lizardi-Ortiz JE, Westphalen RI, Brandstetter M, Hemmings HC Jr, Sulzer D, Flajolet M, Greengard P. AGAP1/AP-3-dependent endocytic recycling of M5 muscarinic receptors promotes dopamine release. EMBO J. 2010; 29:2813-2826. [PubMed: 20664521] 
Besson MJ, Cheramy A, Feltz P, Glowinski J. Release of newly synthesized dopamine from dopaminecontaining terminals in the striatum of the rat. Proc Natl Acad Sci U S A. 1969; 62:741-748. [PubMed: 4389748]

Betke KM1, Wells CA, Hamm HE. GPCR mediated regulation of synaptic transmission. Progress in neurobiology. 2012; 96:304-321. [PubMed: 22307060]

Bromberg-Martin ES, Matsumoto M, Hikosaka O. Dopamine in motivational control: rewarding, aversive, and alerting. Neuron. 2010; 68:815-834. [PubMed: 21144997]

Buczynski MW, Herman MA, Hsu KL, Natividad LA, Irimia C, Polis IY, Pugh H, Chang JW, Niphakis MJ, Cravatt BF, Roberto M, Parsons LH. Diacylglycerol lipase disinhibits VTA dopamine neurons during chronic nicotine exposure. Proc Natl Acad Sci U S A. 2016. 2016; 113:1086-1091.

Bustos G, Roth RH. Release of monoamines from the striatum and hypothalamus: effect of hydroxybutyrate. Br J Pharmacol. 1972; 46:101-115. [PubMed: 5084815]

Cachope R, Cheer JF. Local control of striatal dopamine release. Front Behav Neurosci. 2014; 8:188. [PubMed: 24904339]

Cachope R, Mateo Y, Mathur BN, Irving J, Wang HL, Morales M, Lovinger DM, Cheer JF. Selective activation of cholinergic interneurons enhances accumbal phasic dopamine release: setting the tone for reward processing. Cell Rep. 2012; 2:33-41. [PubMed: 22840394]

Carboni E, Tanda GL, Frau R, Di Chiara G. Blockade of the noradrenaline carrier increases extracellular dopamine concentrations in the prefrontal cortex: evidence that dopamine is taken up in vivo by noradrenergic terminals. J Neurochem. 1990; 55:1067-1070. [PubMed: 2117046]

Carey MR, Myoga MH, McDaniels KR, Marsicano G, Lutz B, Mackie K, Regehr WG. Presynaptic CB1 receptors regulate synaptic plasticity at cerebellar parallel fiber synapses. J Neurophysiol. 2011; 105:958-63. [PubMed: 21084685]

Carlsson A, Lindqvist M, Magnusson T, Waldeck B. On the presence of 3-hydroxytyramine in brain. Science. 1958; 127:471. [PubMed: 13529006]

Castillo PE, Younts TJ, Chávez AE, Hashimotodani Y. Endocannabinoid signaling and synaptic function. Neuron. 2012; 76:70-81. [PubMed: 23040807]

Caulfield MP, Brown DA. Cannabinoid receptor agonists inhibit Ca current in NG108-15 neuroblastoma cells via a pertussis toxin-sensitive mechanism. Br J Pharmacol. 1992; 106:231232. [PubMed: 1327374]

Cheer JF, Kendall DA, Marsden CA. Cannabinoid receptors and reward in the rat: a conditioned place preference study. Psychopharmacology (Berl). 2000; 151:25-30. [PubMed: 10958113]

Cheer JF, Kendall DA, Mason R, Marsden CA. Differential cannabinoid-induced electrophysiological effects in rat ventral tegmentum. Neuropharmacology. 2003; 44:633-641. [PubMed: 12668049]

Cheer JF, Wassum KM, Heien ML, Phillips PE, Wightman RM. Cannabinoids enhance subsecond dopamine release in the nucleus accumbens of awake rats. J Neurosci. 2004; 24:4393-4400. [PubMed: 15128853]

Cheer JF, Wassum KM, Sombers LA, Heien ML, Ariansen JL, Aragona BJ, Phillips PE, Wightman RM. Phasic dopamine release evoked by abused substances requires cannabinoid receptor activation. J Neurosci. 2007; 27:791-795. [PubMed: 17251418]

Chen Q, Veenman L, Knopp K, Yan Z, Medina L, Song WJ, Surmeier DJ, Reiner A. Evidence for the preferential localization of glutamate receptor-1 subunits of AMPA receptors to the dendritic spines of medium spiny neurons in rat striatum. NeuroScience. 1998; 83:749-761. [PubMed: 9483559]

Chevaleyre V, Heifets BD, Kaeser PS, Südhof TC, Castillo PE. Endocannabinoid-mediated long-term plasticity requires cAMP/PKA signaling and RIM1alpha. Neuron. 2007; 54:801-12. [PubMed: 17553427]

Covey DP, Bunner KD, Schuweiler DR, Cheer JF, Garris PA. Amphetamine elevates nucleus accumbens dopamine via an action potential-dependent mechanism that is modulated by endocannabinoids. Eur J Neurosci. 2016; 43:1661-1673. [PubMed: 27038339]

Di Chiara G, Imperato A. Drugs abused by humans preferentially increase synaptic dopamine concentrations in the mesolimbic system of freely moving rats. Proc Natl Acad Sci U S A. 1988; 85:5274-5278. [PubMed: 2899326] 
Exley R, Cragg SJ. Presynaptic nicotinic receptors: a dynamic and diverse cholinergic filter of striatal dopamine neurotransmission. Br J Pharmacol. 2008; (153 Suppl 1):S283-297. [PubMed: 18037926]

Fattore L, Fadda P, Fratta W. Endocannabinoid regulation of relapse mechanisms. Pharmacol Res. 2007; 56:418-427. [PubMed: 17936008]

Fitzgerald ML, Shobin E, Pickel VM. Cannabinoid modulation of the dopaminergic circuitry: implications for limbic and striatal output. Prog. Neuropsychopharmacol. Biol. Psychiatry. 2012; 38:21-29. [PubMed: 22265889]

Ford CP, Phillips PE, Williams JT. The time course of dopamine transmission in the ventral tegmental area. J Neurosci. 2009; 29:13344-13352. [PubMed: 19846722]

Foster DJ, Gentry PR, Lizardi-Ortiz JE, Bridges TM, Wood MR, Niswender CM, Sulzer D, Lindsley $\mathrm{CW}$, Xiang Z, Conn PJ. M5 receptor activation produces opposing physiological outcomes in dopamine neurons depending on the receptor's location. J Neurosci. 2014; 34:3253-3262. [PubMed: 24573284]

Foster DJ, Wilson JM, Remke DH, Mahmood MS, Uddin MJ, Wess J, Patel S, Marnett LJ, Niswender CM, Jones CK, Xiang Z, Lindsley CW, Rook JM, Conn PJ. Antipsychotic-like Effects of M4 Positive Allosteric Modulators Are Mediated by CB2 Receptor-Dependent Inhibition of Dopamine Release. Neuron. 91:1244-1252.

French ED, Dillon K, Wu X. Cannabinoids excite dopamine neurons in the ventral tegmentum and substantia nigra. Neuroreport. 1997; 8:649-652. [PubMed: 9106740]

García C, Palomo-Garo C, Gómez-Gálvez Y, Fernández-Ruiz J. Cannabinoid-dopamine interactions in the physiology and physiopathology of the basal ganglia. Br J Pharmacol. 2016; 173:2069-2079. [PubMed: 26059564]

Gerdeman G, Lovinger DM. CB1 cannabinoid receptor inhibits synaptic release of glutamate in rat dorsolateral striatum. J Neurophysiol. 2001; 85:468-471. [PubMed: 11152748]

Graham JD, Lewis MJ, Li DM. The effect of delta1-tetrahydrocannabinol on the release of (3H-(-)noradrenaline from the isolated vas deferens of the rat. Br J Pharmacol. 1974; 52:233-236. [PubMed: 4451818]

Hashimotodani Y, Ohno-Shosaku T, Tsubokawa H, Ogata H, Emoto K, Maejima T, Araishi K, Shin HS, Kano M. Phospholipase Cbeta serves as a coincidence detector through its $\mathrm{Ca} 2+$ dependency for triggering retrograde endocannabinoid signal. Neuron. 2005; 45:257-68. [PubMed: 15664177]

Hashimotodani Y, Ohno-Shosaku T, Kano M. Ca(2+)-assisted receptor-driven endocannabinoid release: mechanisms that associate presynaptic and postsynaptic activities. Curr. Opin. Neurobiol. 2007; 17:360-365. [PubMed: 17419048]

Heifets BD, Chevaleyre V, Castillo PE. Interneuron activity controls endocannabinoid-mediated presynaptic plasticity through calcineurin. Proc Natl Acad Sci U S A. 2008; 105:10250-10255. [PubMed: 18632563]

Heinbockel T, Brager DH, Reich CG, Zhao J, Muralidharan S, Alger BE, Kao JP. Endocannabinoid signaling dynamics probed with optical tools. J Neurosci. 2005; 25:9449-9459. [PubMed: 16221855]

Herkenham M, Lynn AB, Little MD, Johnson MR, Melvin LS, de Costa BR, Rice KC. Cannabinoid receptor localization in brain. Proc Natl Acad Sci USA. 1990; 87:1932-1936. [PubMed: 2308954]

Higley MJ1, Gittis AH, Oldenburg IA, Balthasar N, Seal RP, Edwards RH, Lowell BB, Kreitzer AC, Sabatini BL. Cholinergic interneurons mediate fast VGluT3-dependent glutamatergic transmission in the striatum. PLoS One. 2011; 6:e19155. [PubMed: 21544206]

Hilário MR, Costa RM. High on habits. Front Neurosci. 2008; 2:208-217. [PubMed: 19225594]

Hillarp NA, Fuxe K, Dahlström A. Demonstration and mapping of central neurons containing dopamine, noradrenaline, and 5-hydroxytryptamine and their reactions to psychopharmaca. Pharmacol Rev. 1966; 18:727-741. [PubMed: 5904678]

Hohmann AG, Herkenham M. Localization of cannabinoid CB(1) receptor mRNA in neuronal subpopulations of rat striatum: a double-label in situ hybridization study. Synapse. 2000; 37:7180. [PubMed: 10842353]

Hyman SE, Malenka RC, Nestler EJ. Neural mechanisms of addiction: the role of reward-related learning and memory. Annu Rev Neurosci. 2006; 29:565-598. [PubMed: 16776597] 
Ishac EJ, Jiang L, Lake KD, Varga K, Abood ME, Kunos G. Inhibition of exocytotic noradrenaline release by presynaptic cannabinoid CB1 receptors on peripheral sympathetic nerves. $\mathrm{Br} \mathrm{J}$ Pharmacol. 1996; 118:2023-2028. [PubMed: 8864538]

Iversen, LL., Iversen, SD., Dunnett, SB., Björklund, A. The Dopamine Handbook. Oxford University Press; New York: 2010.

Jin X, Costa RM. Shaping action sequences in basal ganglia circuits. Curr Opin Neurobiol. 2015; 33:188-196. [PubMed: 26189204]

Julian MD, Martin AB, Cuellar B, Rodriguez De Fonseca F, Navarro M, Moratalla R, Garcia-Segura LM. Neuroanatomical relationship between type 1 cannabinoid receptors and dopaminergic systems in the rat basal ganglia. NeuroScience. 2003; 119:309-318. [PubMed: 12763090]

Kano M, Ohno-Shosaku T, Hashimotodani Y, Uchigashima M, Watanabe M. Endocannabinoidmediated control of synaptic transmission. Physiol Rev. 2009; 89:309-80. [PubMed: 19126760]

Katona I, Freund TF. Multiple functions of endocannabinoid signaling in the brain. Annu Rev Neurosci. 2012; 35:529-558. [PubMed: 22524785]

Krebs MO, Desce JM, Kemel ML, Gauchy C, Godeheu G, Cheramy A, Glowinski J. Glutamatergic control of dopamine release in the rat striatum: evidence for presynaptic N-methyl-D-aspartate receptors on dopaminergic nerve terminals. J Neurochem. 1991; 56:81-85. [PubMed: 1824785]

Kreitzer AC, Regehr WG. Retrograde inhibition of presynaptic calcium influx by endogenous cannabinoids at excitatory synapses onto Purkinje cells. Neuron. 2001; 29:717-727. [PubMed: 11301030]

Kortleven C, Bruneau LC, Trudeau LE. Neurotensin inhibits glutamate-mediated synaptic inputs onto ventral tegmental area dopamine neurons through the release of the endocannabinoid 2-AG. Neuropharmacology. 2012; 63:983-991. [PubMed: 22884466]

Kosillo P, Zhang YF, Threlfell S, Cragg SJ. Cortical Control of Striatal Dopamine Transmission via Striatal Cholinergic Interneurons. Cereb Cortex. 2016; 26:4160-4169.

Kulagina NV, Zigmond MJ, Michael AC. Glutamate regulates the spontaneous and evoked release of dopamine in the rat striatum. NeuroScience. 2001; 102:121-128. [PubMed: 11226675]

Labouèbe G, Liu S, Dias C, Zou H, Wong JC, Karunakaran S, Clee SM, Phillips AG, Boutrel B, Borgland SL. Insulin induces long-term depression of ventral tegmental area dopamine neurons via endocannabinoids. Nat Neurosci. 2013; 16:300-308. [PubMed: 23354329]

Lachowicz JE, Sibley DR. Molecular characteristics of mammalian dopamine receptors. Pharmacol Toxicol. 1997; 81:105-113. [PubMed: 9335067]

Lafourcade M, Elezgarai I, Mato S, Bakiri Y, Grandes P, Manzoni OJ. Molecular components and functions of the endocannabinoid system in mouse prefrontal cortex. PLoS One. 2007; 2:e709. [PubMed: 17684555]

Lammel S, Lim BK, Malenka RC. Reward and aversion in a heterogeneous midbrain dopamine system. Neuropharmacology. 2014; 76(Pt B):351-359. [PubMed: 23578393]

Lazary J, Juhasz G, Hunyady L, Bagdy G. Personalized medicine can pave the way for the safe use of CBD receptor antagonists. Trends Pharmacol Sci. 2011; 32:270-280. [PubMed: 21497918]

Latek D, Modzelewska A, Trzaskowski B, Palczewski K, Filipek S. G protein-coupled receptors-recent advances. Acta Biochim Pol. 2012; 59:515-529. [PubMed: 23251911]

Liu QR, Pan CH, Hishimoto A, Li CY, Xi ZX, Llorente-Berzal A, Viveros MP, Ishiguro H, Arinami T, Onaivi ES, Uhl GR. Species differences in cannabinoid receptor 2 (CNR2 gene): identification of novel human and rodent CB2 isoforms, differential tissue expression and regulation by cannabinoid receptor ligands. Genes Brain Behav. 2009; 8:519-30. [PubMed: 19496827]

Liu QS, Pu L, Poo MM. Repeated cocaine exposure in vivo facilitates LTP induction in midbrain dopamine neurons. Nature. 2005; 437:1027-1031. [PubMed: 16222299]

Lobb CJ, Wilson CJ, Paladini CA. A dynamic role for GABA receptors on the firing pattern of midbrain dopaminergic neurons. J Neurophysiol. 2010; 104:403-413. [PubMed: 20445035]

Lupica CR, Riegel AC. Endocannabinoid release from midbrain dopamine neurons: a potential substrate for cannabinoid receptor antagonist treatment of addiction. Neuropharmacology. 2005; 48:1105-1116. [PubMed: 15878779]

Lu HC, Mackie K. An Introduction to the Endogenous Cannabinoid System. Biol Psychiatry. 2016; 79:516-525. [PubMed: 26698193] 
Luscher C. Drug-evoked synaptic plasticity causing addictive behavior. J Neurosci. 2013; 33:1764117646. [PubMed: 24198356]

Mackie K, Zimmer A, Chiou LC. Orexins contribute to restraint stress-induced cocaine relapse by endocannabinoid-mediated disinhibition of dopaminergic neurons. Nat Commun. 2016; 7:12199. [PubMed: 27448020]

Maejima T, Hashimoto K, Yoshida T, Aiba A, Kano M. Presynaptic inhibition caused by retrograde signal from metabotropic glutamate to cannabinoid receptors. Neuron. 2001; 31:463-475. [PubMed: 11516402]

Margolis EB, Lock H, Hjelmstad GO, Fields HL. The ventral tegmental area revisited: is there an electrophysiological marker for dopaminergic neurons? J Physiol. 2006; 577(Pt 3):907-924. [PubMed: 16959856]

Mato S, Lafourcade M, Robbe D, Bakiri Y, Manzoni OJ. Role of the cyclic-AMP/PKA cascade and of $\mathrm{P} / \mathrm{Q}$-type $\mathrm{Ca}++$ channels in endocannabinoid-mediated long-term depression in the nucleus accumbens. Neuropharmacology. 2008; 54:87-94. [PubMed: 17606273]

Martín AB, Fernandez-Espejo E, Ferrer B, Gorriti MA, Bilbao A, Navarro M, Rodriguez de Fonseca F, Moratalla R. Expression and function of CB1 receptor in the rat striatum: localization and effects on D1 and D2 dopamine receptor-mediated motor behaviors. Neuropsychopharmacology. 2008; 33:1667-1679. [PubMed: 17957223]

Matyas F, Urban GM, Watanabe M, Mackie K, Zimmer A, Freund TF, Katona I. Identification of the sites of 2-arachidonoylglycerol synthesis and action imply retrograde endocannabinoid signaling at both GABAergic and glutamatergic synapses in the ventral tegmental area. Neuropharmacology. 2008; 54:95-107. [PubMed: 17655884]

Melis M, De Felice M, Lecca S, Fattore L, Pistis M. Sex-specific tonic 2-arachidonoylglycerol signaling at inhibitory inputs onto dopamine neurons of Lister Hooded rats. Front Integr Neurosci. 2013; 7:93. [PubMed: 24416004]

Melis M, Perra S, Muntoni AL, Pillolla G, Lutz B, Marsicano G, Di Marzo V, Gessa GL, Pistis M. Prefrontal cortex stimulation induces 2-arachidonoyl-glycerol-mediated suppression of excitation in dopamine neurons. J Neurosci. 2004; 24:10707-10715. [PubMed: 15564588]

Melis M, Pistis M, Perra S, Muntoni AL, Pillolla G, Gessa GL. Endocannabinoids mediate presynaptic inhibition of glutamatergic transmission in rat ventral tegmental area dopamine neurons through activation of CB1 receptors. J Neurosci. 2004; 24:53-62. [PubMed: 14715937]

Melis M, Pillolla G, Bisogno T, Minassi A, Petrosino S, Perra S, Muntoni AL, Lutz B, Gessa GL, Marsicano G, Di Marzo V, Pistis M. Protective activation of the endocannabinoid system during ischemia in dopamine neurons. Neurobiol Dis. 2006; 24:15-27. [PubMed: 16762556]

Morikawa H, Khodakhah K, Williams JT. Two intracellular pathways mediate metabotropic glutamate receptor-induced $\mathrm{Ca} 2+$ mobilization in dopamine neurons. J Neurosci. 2003; 23:149-157. [PubMed: 12514211]

Munro S, Thomas KL, Abu-Shaar M. Molecular characterization of a peripheral receptor for cannabinoids. Nature. 1993; 365:61-65. [PubMed: 7689702]

Narushima M, Uchigashima M, Fukaya M, Matsui M, Manabe T, Hashimoto K, Watanabe M, Kano $\mathrm{M}$. Tonic enhancement of endocannabinoid-mediated retrograde suppression of inhibition by cholinergic interneuron activity in the striatum. J Neurosci. 2007; 27:496-506. [PubMed: 17234582]

Katona I, Sperlágh B, Sík A, Käfalvi A, Vizi ES, Mackie K, Freund TF. Presynaptically located CB1 cannabinoid receptors regulate GABA release from axon terminals of specific hippocampal interneurons. J Neurosci. 1999; 19:4544-4558. [PubMed: 10341254]

Kushmerick C, Price GD, Taschenberger H, Puente N, Renden R, Wadiche JI, Duvoisin RM, Grandes $\mathrm{P}$, von Gersdorff $\mathrm{H}$. Retroinhibition of presynaptic $\mathrm{Ca} 2+$ currents by endocannabinoids released via postsynaptic mGluR activation at a calyx synapse. J Neurosci. 2004; 24:5955-5965. [PubMed: 15229243]

Mackie K, Hille B. Cannabinoids inhibit N-type calcium channels in neuroblastoma-glioma cells. Proc Natl Acad Sci U S A. 1992; 89:3825-3829. [PubMed: 1315042]

Nelson AB, Bussert TG, Kreitzer AC, Seal RP. Striatal cholinergic neurotransmission requires VGLUT3. J Neurosci. 2014; 34:8772-8777. [PubMed: 24966377] 
Neve KA1, Seamans JK, Trantham-Davidson H. Dopamine receptor signaling. J Recept Signal Transduct Res. 2010; 24:165-205.

Nieh EH, Vander Weele CM, Matthews GA, Presbrey KN, Wichmann R, Leppla CA, Izadmehr EM, Tye KM. Inhibitory Input from the Lateral Hypothalamus to the Ventral Tegmental Area Disinhibits Dopamine Neurons and Promotes Behavioral Activation. Neuron. 2016; 90:12861298. [PubMed: 27238864]

Nyiri G, Cserep C, Szabadits E, Mackie K, Freund TF. CB1 cannabinoid receptors are enriched in the perisynaptic annulus and on preterminal segments of hippocampal GABAergic axons. NeuroScience. 2005; 136:811-822. [PubMed: 16344153]

Ohno-Shosaku T, Maejima T, Kano M. Endogenous cannabinoids mediate retrograde signals from depolarized postsynaptic neurons to presynaptic terminals. Neuron. 2001; 29:729-738. [PubMed: 11301031]

Ohno-Shosaku T, Kano M. Endocannabinoid-mediated retrograde modulation of synaptic transmission. Curr Opin Neurobiol. 2014; 29:1-8. [PubMed: 24747340]

Oldham WM, Hamm HE. Structural basis of function in heterotrimeric G proteins. Quarterly reviews of biophysics. 2006; 39:117-166. [PubMed: 16923326]

Oleson EB, Beckert MV, Morra JT, Lansink CS, Cachope R, Abdullah RA, Loriaux AL, Schetters D, Pattij T, Roitman MF, Lichtman AH, Cheer JF. Endocannabinoids shape accumbal encoding of cue-motivated behavior via CB1 receptor activation in the ventral tegmentum. Neuron. 2012; 73:360-373. [PubMed: 22284189]

Oleson EB, Gentry RN, Chioma VC, Cheer JF. Subsecond dopamine release in the nucleus accumbens predicts conditioned punishment and its successful avoidance. J Neurosci. 2012; 32:14804-14808. [PubMed: 23077064]

Paladini, CA., Tepper, JM. Neurophysiology of substantia nigra dopamine neurons: Modulation by GABA and glutamate. In: Steiner, H., Tseng, KY., editors. Handbook of Basal Ganglia Structure and function. Elsevier/Academic Press; New York, NY: 2017. p. 335-360.

Pan B, Hillard CJ, Liu QS. Endocannabinoid signaling mediates cocaine-induced inhibitory synaptic plasticity in midbrain dopamine neurons. J Neurosci. 2008; 28:1385-1397. [PubMed: 18256258]

Parsons LH, Hurd YL. Endocannabinoid signaling in reward and addiction. Nat Rev Neurosci. 2015; 16:579-594. [PubMed: 26373473]

Paquet M, Smith Y. Group I metabotropic glutamate receptors in the monkey striatum: subsynaptic association with glutamatergic and dopaminergic afferents. J Neurosci. 2003; 23:7659-7669. [PubMed: 12930805]

Plotkin JL, Shen W, Rafalovich I, Sebel LE, Day M, Chan CS, Surmeier DJ. Regulation of dendritic calcium release in striatal spiny projection neurons. JNeurophysiol. 2013; 110:2325-2336. [PubMed: 23966676]

Qi J, Zhang S, Wang HL, Wang H, de Jesus Aceves Buendia J, Hoffman AF, Lupica CR, Seal RP, Morales M. A glutamatergic reward input from the dorsal raphe to ventral tegmental area dopamine neurons. Nat Commun. 2014; 5:5390. [PubMed: 25388237]

Rapier C, Lunt GG, Wonnacott S. Nicotinic modulation of $[3 \mathrm{H}]$ dopamine release from striatal synaptosomes: pharmacological characterisation. J Neurochem. 1990; 54:937-945. [PubMed: 2303820]

Riegel AC, Lupica CR. Independent presynaptic and postsynaptic mechanisms regulate endocannabinoid signaling at multiple synapses in the ventral tegmental area. J Neurosci. 2004; 24:11070-11078. [PubMed: 15590923]

Roitman MF, Wheeler RA, Wightman RM, Carelli RM. Real-time chemical responses in the nucleus accumbens differentiate rewarding and aversive stimuli. Nat Neurosci. 2008; 11:1376-1377. [PubMed: 18978779]

Ronesi J, Lovinger DM. Induction of striatal long-term synaptic depression by moderate frequency activation of cortical afferents in rat. J Physiol. 2005; 562(1):245-56. [PubMed: 15498813]

Scherman D, Raisman R, Ploska A, Agid Y. [3H]dihydrotetrabenazine, a new in vitro monoaminergic probe for human brain. 1988; 50:1131-1136. 
Shen M, Piser TM, Seybold VS, Thayer SA. Cannabinoid receptor agonists inhibit glutamatergic synaptic transmission in rat hippocampal cultures. J Neurosci. 1996; 16:4322-4334. [PubMed: 8699243]

Shin JH, Adrover MF, Wess J, Alvarez VA. Muscarinic regulation of dopamine and glutamate transmission in the nucleus accumbens. Proc Natl Acad Sci U S A. 2015; 112:8124-8129. [PubMed: 26080439]

Sidló Z, Reggio PH, Rice ME. Inhibition of striatal dopamine release by CB1 receptor activation requires nonsynaptic communication involving GABA, H2O2, and KATP channels. Neurochem Int. 2008; 52:80-88. [PubMed: 17767979]

Stamatakis AM, Jennings JH, Ung RL, Blair GA, Weinberg RJ, Neve RL, Boyce F, Mattis J, Ramakrishnan C, Deisseroth K, Stuber GD. A unique population of ventral tegmental area neurons inhibits the lateral habenula to promote reward. Neuron. 2013; 80:1039-1053. [PubMed: 24267654]

Subramaniam, M., Roeper, J. Subtypes of midbrain dopamine neurons. In: Steiner, H., Tseng, KY., editors. Handbook of Basal Ganglia Structure and function. Elsevier/Academic Press; New York, NY: 2017. p. 317-334.

Sulzer D, Cragg SJ, Rice ME. Striatal dopamine neurotransmission: regulation of release and uptake. Basal ganglia. 2016; 6:123-148. [PubMed: 27141430]

Sulzer, D., Cragg, SJ., Rice, ME. Regulation of extracellular dopamine: Release and uptake. In: Steiner, H., Tseng, KY., editors. Handbook of Basal Ganglia Structure and Function. Elsevier/ Academic Press; New York, NY: 2017. p. 373-402.

Syed EC, Grima LL, Magill PJ, Bogacz R, Brown P, Walton ME. Action initiation shapes mesolimbic dopamine encoding of future rewards. Nat Neurosci. 2016; 19:34-6. [PubMed: 26642087]

Szabo B, Müller T, Koch H. Effects of cannabinoids on dopamine release in the corpus striatum and the nucleus accumbens in vitro. J Neurochem. 1999; 73:1084-1089. [PubMed: 10461898]

Szabo B, Siemes S, Wallmichrath I. Inhibition of GABAergic neurotransmission in the ventral tegmental area by cannabinoids. Eur J Neurosci. 2002; 15:2057-2061. [PubMed: 12099913]

Tanda G, Pontieri FE, Di Chiara G. Cannabinoid and heroin activation of mesolimbic dopamine transmission by a common mu1 opioid receptor mechanism. Science. 1997; 276:2048-250. [PubMed: 9197269]

Tanimura A, Yamazaki M, Hashimotodani Y, Uchigashima M, Kawata S, Abe M, Kita Y, Hashimoto K, Shimizu T, Watanabe M, Sakimura K, Kano M. The endocannabinoid 2-arachidonoylglycerol produced by diacylglycerol lipase alpha mediates retrograde suppression of synaptic transmission. Neuron. 2010; 65:320-327. [PubMed: 20159446]

Threlfell S, Lalic T, Platt NJ, Jennings KA, Deisseroth K, Cragg SJ. Striatal dopamine release is triggered by synchronized activity in cholinergic interneurons. Neuron. 2012; 75:58-64. [PubMed: 22794260]

Tsou K, Brown S, Sanudo-Pena MC, Mackie K, Walker JM. Immunohistochemical distribution of cannabinoid CB1 receptors in the rat central nervous system. NeuroScience. 1998; 83:393-411. [PubMed: 9460749]

Tung LW, Lu GL, Lee YH, Yu L, Lee HJ, Leishman E, Bradshaw H, Hwang LL, Hung MS. Orexins contribute to restraint stress-induced cocaine relapse by endocannabinoid-mediated disinhibition of dopaminergic neurons. Nat Commun. 2016; 7:12199. [PubMed: 27448020]

Uchigashima M, Narushima M, Fukaya M, Katona I, Kano M, Watanabe M. Subcellular arrangement of molecules for 2-arachidonoyl-glycerol-mediated retrograde signaling and its physiological contribution to synaptic modulation in the striatum. J Neurosci. 2007; 27:3663-3676. [PubMed: 17409230]

Ungless MA, Magill PJ, Bolam JP. Uniform inhibition of dopamine neurons in the ventral tegmental area by aversive stimuli. Science. 2004; 303:2040-2042. [PubMed: 15044807]

Ungless MA, Grace AA. Are you or aren't you? Challenges associated with physiologically identifying dopamine neurons. Trends Neurosci. 2012; 35:422-430. [PubMed: 22459161]

Varma N, Carlson GC, Ledent C, Alger BE. Metabotropic glutamate receptors drive the endocannabinoid system in hippocampus. J Neurosci. 2001; 21:RC188. [PubMed: 11734603] 
Wang W, Dever D, Lowe J, Storey GP, Bhansali A, Eck EK, Nitulescu I, Weimer J, Bamford NS. Regulation of prefrontal excitatory neurotransmission by dopamine in the nucleus accumbens core. J Physiol. 2012; 590:3743-3769. [PubMed: 22586226]

Wang H, Treadway T, Covey DP, Cheer JF, Lupica CR. Cocaine-Induced Endocannabinoid Mobilization in the Ventral Tegmental Area. Cell Rep. 2015; 12:1997-2008. [PubMed: 26365195]

Watabe-Uchida M, Zhu L, Ogawa SK, Vamanrao A, Uchida N. Whole-brain mapping of direct inputs to midbrain dopamine neurons. Neuron. 2012; 74:858-73. [PubMed: 22681690]

Wiebelhaus JM, Grim TW, Owens RA, Lazenka MF, Sim-Selley LJ, Abdullah RA, Niphakis MJ, Vann RE, Cravatt BF, Wiley JL, Negus SS, Lichtman AH. $\Delta$ 9-tetrahydrocannabinol and endocannabinoid degradative enzyme inhibitors attenuate intracranial self-stimulation in mice. $\mathbf{J}$ Pharmacol Exp Ther. 2015; 352:195-207. [PubMed: 25398241]

Wilson RI, Nicoll RA. Endogenous cannabinoids mediate retrograde signaling at hippocampal synapses. Nature. 2001; 410:588-592. [PubMed: 11279497]

Wong MY, Sulzer D, Bamford NS. Imaging presynaptic exocytosis in corticostriatal slices. Methods Mol Biol. 2011; 793:363-376. [PubMed: 21913113]

Wu Y, Pearl SM, Zigmond MJ, Michael AC. Inhibitory glutamatergic regulation of evoked dopamine release in striatum. NeuroScience. 2000; 96:65-72. [PubMed: 10683411]

Xi ZX, Peng XQ, Li X, Song R, Zhang HY, Liu QR, Yang HJ, Bi GH, Li J, Gardner EL. Brain cannabinoid CB $\square$ receptors modulate cocaine's actions in mice. Nat Neurosci. 2011; 14:11601166. [PubMed: 21785434]

Yin HH, Davis MI, Ronesi JA, Lovinger DM. The role of protein synthesis in striatal long-term depression. J Neurosci. 2006; 26:11811-11820. [PubMed: 17108154]

Yin HH, Lovinger DM. Frequency-specific and D2 receptor-mediated inhibition of glutamate release by retrograde endocannabinoid signaling. Proc Natl Acad Sci U S A. 2006; 103:8251-8256. [PubMed: 16698932]

Younts TJ, Monday HR, Dudok B, Klein ME, Jordan BA, Katona I, Castillo PE. Presynaptic Protein Synthesis Is Required for Long-Term Plasticity of GABA Release. Neuron. 2016; 92:479-492. [PubMed: 27764673]

Zhang L, Doyon WM, Clark JJ, Phillips PE, Dani JA. Controls of tonic and phasic dopamine transmission in the dorsal and ventral striatum. Mol Pharmacol. 2009; 76:396-404. [PubMed: 19460877]

Zhang HY, Bi GH, Li X, Li J, Qu H, Zhang SJ, Li CY, Onaivi ES, Gardner EL, Xi ZX, Liu QR. Species differences in cannabinoid receptor 2 and receptor responses to cocaine selfadministration in mice and rats. Neuropsychopharmacology. 2015; 40:1037-1051. [PubMed: 25374096]

Zhang HY, Gao M, Liu QR, Bi GH, Li X, Yang HJ, Gardner EL, Wu J, Xi ZX. Cannabinoid CB2 receptors modulate midbrain dopamine neuronal activity and dopamine-related behavior in mice. Proc Natl Acad Sci U S A. 2014; 111:E5007-15. [PubMed: 25368177]

Zhang HY, Gao M, Shen H, Bi GH, Yang HJ, Liu QR, Wu J, Gardner EL, Bonci A, Xi ZX. Expression of functional cannabinoid $\mathrm{CB}_{2}$ receptor in VTA dopamine neurons in rats. Addict Biol. 2016 [Epub ahead of print].

Zhou FM, Liang Y, Dani JA. Endogenous nicotinic cholinergic activity regulates dopamine release in the striatum. Nat Neurosci. 2001; 4:1224-1229. [PubMed: 11713470]

Zhang H, Sulzer D. Glutamate spillover in the striatum depresses dopaminergic transmission by activating group I metabotropic glutamate receptors. J Neurosci. 2003; 23:10585-10592. [PubMed: 14627643]

Zhong P, Liu Y, Hu Y, Wang T, Zhao YP, Liu QS. BDNF interacts with endocannabinoids to regulate cocaine-induced synaptic plasticity in mouse midbrain dopamine neurons. J Neurosci. 2015; 35:4469-4481. [PubMed: 25762688] 


\section{Highlights}

$\square \quad$ The endocannabinoid system controls synaptic transmission via feedback inhibition.

$\square \quad$ Cannabinoid receptors modulate excitatory and inhibitory synaptic plasticity.

$\square \quad$ Endocannabinoids control dopamine neurotransmission at midbrain and forebrain loci.

$\square \quad$ Endocannabinoids filter dopamine input onto downstream targets. 


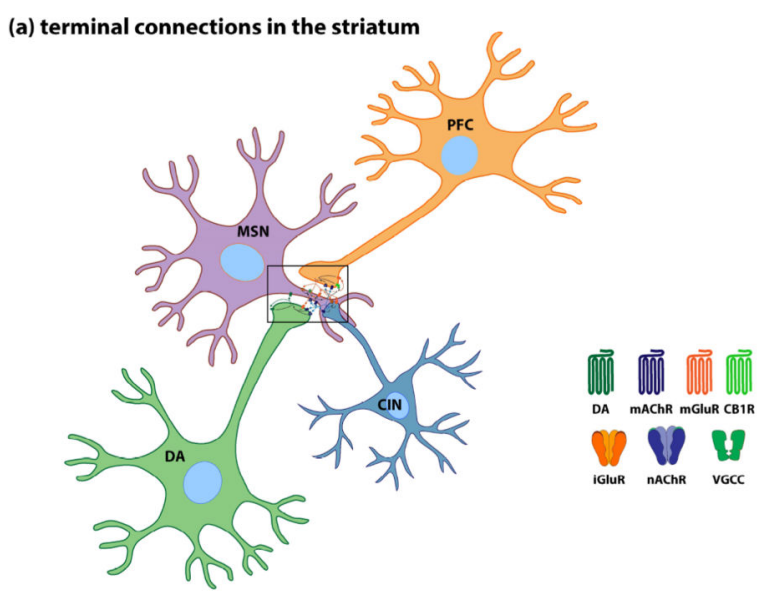

(c) glutamate targets

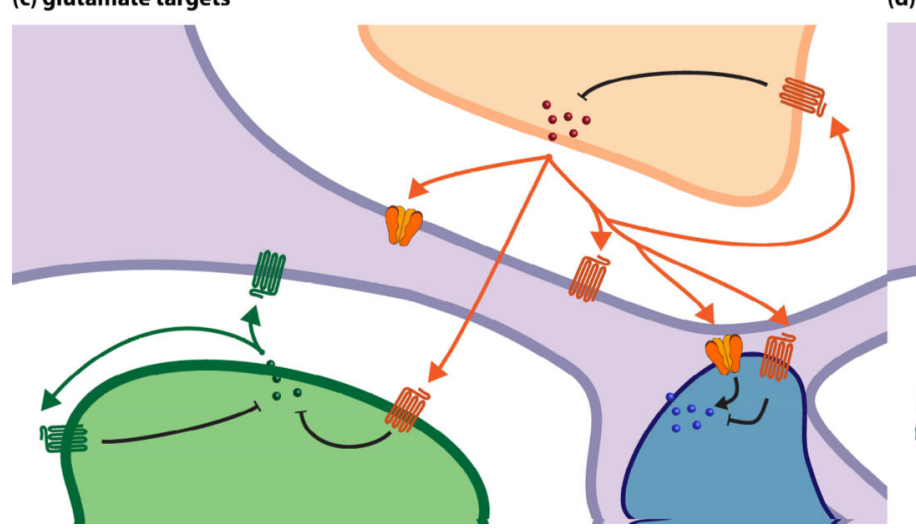

(b) acetylcholine targets

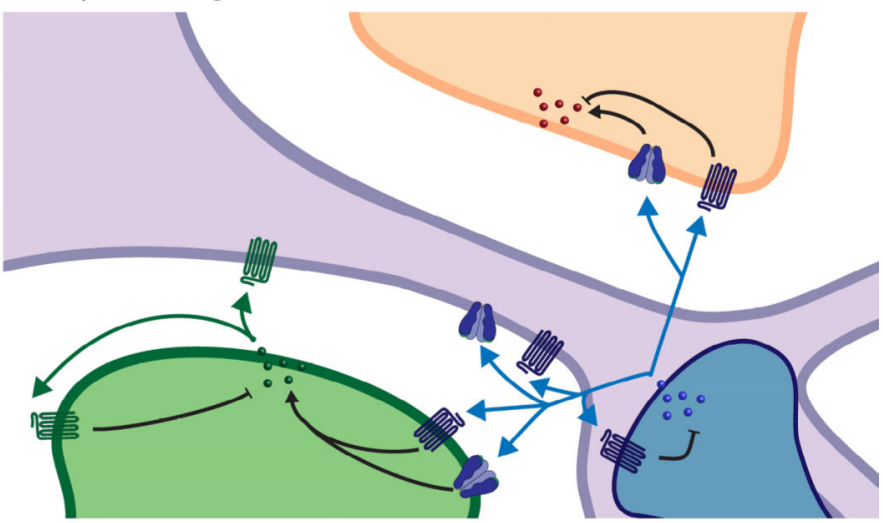

(d) endocannabinoid modulation

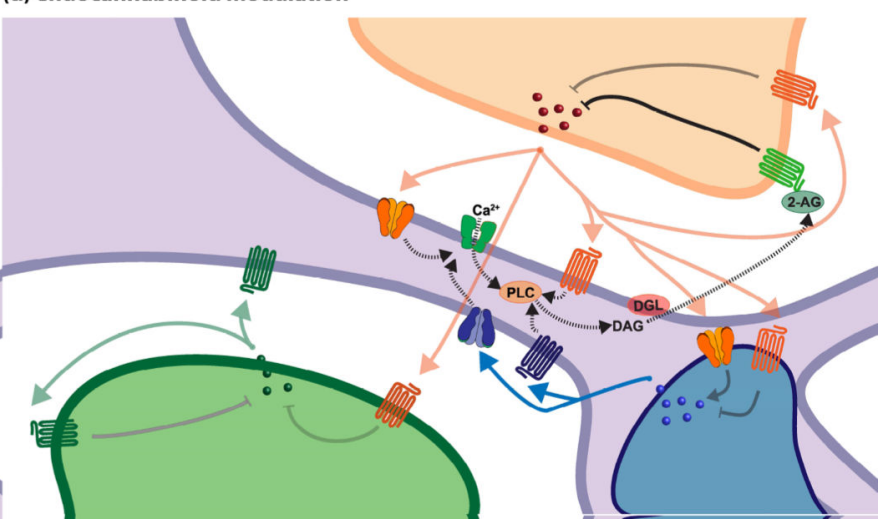

Figure 1.

Modulation of DA release at striatal axon terminals. (A) Striatal medium spiny neurons (MSNs) receive afferent input from the prefrontal cortex (PFC), cholinergic interneurons (CIN), and midbrain DA neurons. Output from each site influences terminal DA release. (B) Acetylcholine released from CINs targets nicotinic acetylcholine receptors (nACh-Rs) and metabotropic acetylcholine receptors (mACh-Rs) at each afferent input site and on MSNs. For simplicity, ACh is depicted as influencing glutamate release via receptor binding on glutamatergic terminals from the PFC. However, the source of glutamate targeted by ACh may also arise from DA or CIN terminals (Shin et al., 2015; Higley et al., 2011; Nelson et al., 2014). (C) Glutamate release from the PFC targets metabotropic glutamate receptors (mGlu-Rs) at each neuronal site and ionotropic glutamate receptors (iGlu-Rs) on CINs and MSNs. (D) Endocannabinoid release from striatal MSNs can be elicited by glutamatergic and cholinergic inputs. Increased calcium $\left(\mathrm{Ca}^{2+}\right)$ flux through voltage-gated $\mathrm{Ca}^{2+}$ channels (VGCCs) following $n A C h-R$ or iGlu-R binding, and $\mathrm{G}_{\mathrm{g} / 11}$-coupled mACh-R or mGlu-R binding both target intracellular phospholipase C (PLC) signaling. Activation of PLC promotes synthesis of diacylglycerol (DAG), which is hydrolyzed by diacylglycerol lipase alpha (DGLa) to form 2-arachidonoylglycerol (2-AG) that is released onto presynaptic cannabinoid type 1 (CB1) receptors on PFC terminals. CB1 receptors are not found on DA terminals (Julian et al., 2003) or CINs (Hohmann and Herkenham, 2000; Uchigashima et al., 2007), but are expressed on glutamate terminals (Uchigashima et al., 2007), where their activation inhibits glutamate release onto output targets. 


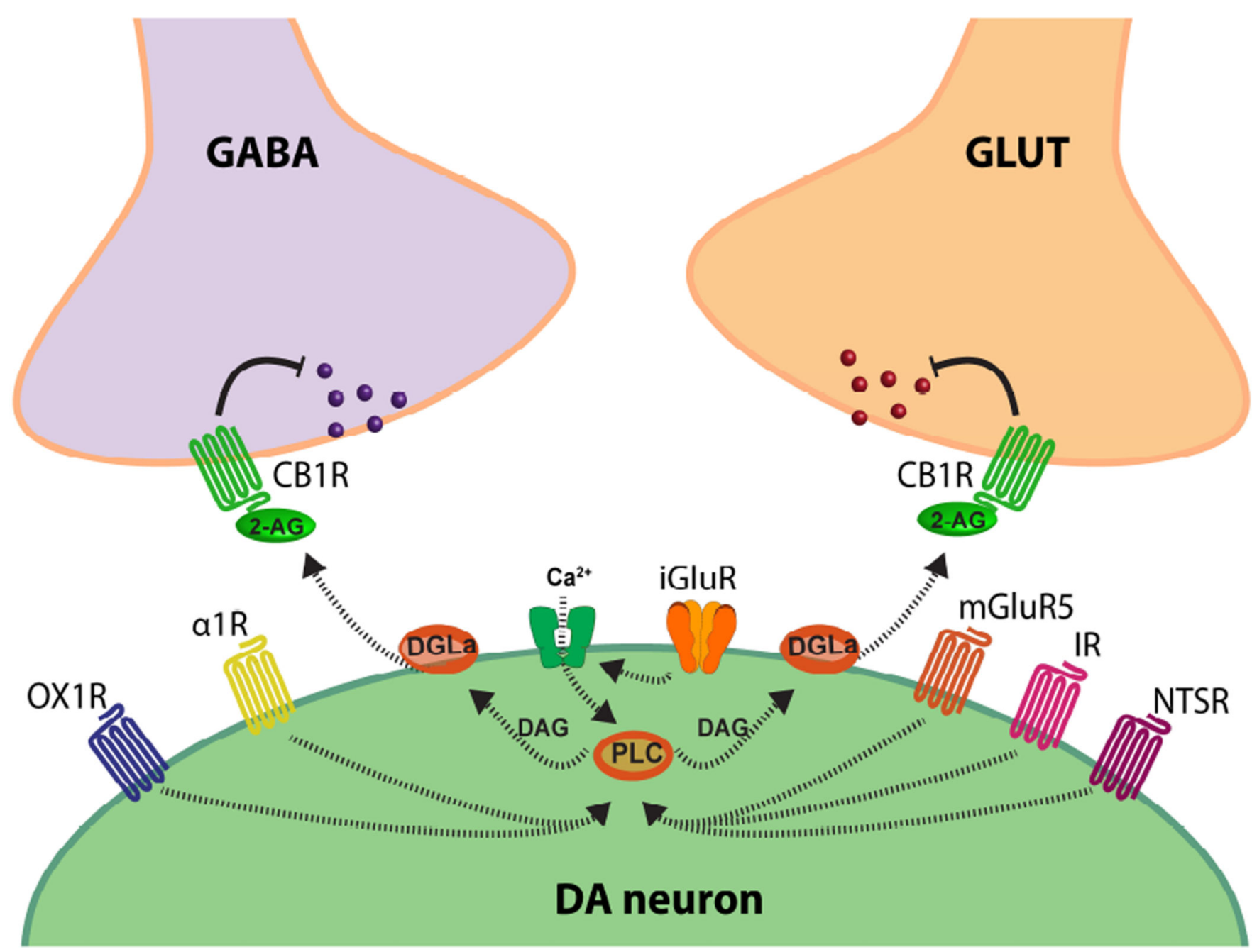

Figure 2.

Endocannabinoid control of midbrain DA neurons. The endocannabinoid 2-AG is synthesized by DA neurons via DGLa and released onto presynaptic CB1 receptors of GABAergic (GABA) and glutamatergic (GLUT) terminals. Several signaling mechanisms target PLC to trigger DGLa activity, including increased $\mathrm{Ca}^{2+}$ flux (e.g., following iGluR signaling) and $\mathrm{G}_{\mathrm{g} / 11}$ GPCR binding. A number of identified $\mathrm{G}_{\mathrm{g} / 11}$ GPCRs drive 2-AG synthesis and CB1 receptor-mediated inhibition of presynaptic input, including type 1 orexin receptors (OX1R; Tung et al., 2016), alpha1 adrenergic receptors (a1R; Wang et al., 2015), mGluR5 glutamate receptors (Wang et al., 2015), insulin receptors (IR; Labouèbe et al., 2013), and neurotensin receptors (NTSR; Kortleven et al., 2012). 